\title{
A Study on the Legislation of Civil Servants Occupation Morality
}

\author{
Xuefeng Lv \\ Hubei Administration College, Wuhan City, Hubei Province, 430022, China
}

Keywords: Occupation morality construction; Civil servant; Legislation

\begin{abstract}
With the deterioration of civil servants moral anomie, countries around the world have paid more attention to the civil servants occupation morality construction, and have explored effective methods of civil servants occupation morality construction. After various attempts, the road of legalization of civil servants occupation morality has been adopted by more and more countries. As the structure and form of civil servants occupation morality, the legalization has become an effective measure to play the regulatory functions of civil servants occupation morality. This paper analyzed the situation of civil servants occupation morality in our country and then described the content of legislation of civil servants occupation morality. Eventually, several solutions were proposed to promote the legislation of civil servants occupation morality.
\end{abstract}

\section{Introduction}

Although our country has thousands of years of moral legalization tradition, western countries first put the civil servants occupation morality into the legal track. At present, our country is in an important historical period of deepening the reform and opening-up policy, but corruption and power-for-money deal are becoming more and more prominent. Civil servants have great discretion, so that conflicts caused by the public interest and private interests, the complexity of public management activities, the normalization of administrative behavior choice dilemmas and the complexity of civil servants professional morality practice, are becoming more and more serious. Therefore, it is essential to promote the civil servants occupation morality construction by legislation. Under the background of this era, we must be guided by rules of law and virtue, and learn from foreign successful practice, so as to strengthen the legalization of civil servants occupation morality combined with China's actual situation.

\section{The Fundamental Guarantee of Civil Servants Occupation Morality Construction}

The morality mainly depends on flexible powers to maintain social stability. On the contrary, the law is much more rigid than morality. Thus, the value of morality is mainly reflected by the self-discipline. However, it is not to say that both of morality and law cannot learn from each other in the maintenance modes. Due to the penetration of morality and law, their maintenance modes rely on each other as well. Therefore, the morality has a rigid side and the law has a soft side.

The civil servants occupation morality construction on legislation ought not to explain from the perspective of relationships between law and morality, but ought to explain from the particularity of civil servants. The occupation morality is different from normal moralities due to its particularity in different occupations. In general, civil servants hold social resources and public powers, which lead to the temptation and corrosiveness. An unfettered power is prone to corruption, which not only damages the public interests, but also brings disastrous consequences to civil servants. In general, civil servants occupation morality sets up a high-voltage line and warning line for official behaviors of civil servants, and provides a reminder for civil servants. However, civil servants occupation morality does not neglect their initiative of moral life. The maintenance of civil servants occupation morality cannot conduct without the moral consciousness and self-discipline. Different morality have different characteristics so that the maintenance power will be different as well. For instance, 
the social morality is the bottom line, and it must rely on the legal power. The civil servants occupation morality should be promoted by external powers, and becomes a faith. When understanding the relationship between occupation morality and their future destiny, civil servants will internalize occupation morality into the moral self-discipline.

To sum up, the civil servants occupation morality, especially the sound corruption system, is the foundation of civil servants occupation morality construction. The legal power is not for negative punishments, but for public and civil servants' interests. In addition, institutions guide human nature. If there is too much tolerance on unethical behaviors, it will make the immoral income is far greater than the cost of this behavior. This situation is unfair for civil servants to abide with occupation morality, and plays a bad demonstration to civil servants.

\section{The Content of Civil Servants Occupation Morality}

The civil servants occupation morality is a system engineering, including civil servant ethical legalization, institutionlization of civil servant morality in specific departments and optimization of external security. The civil servant ethical legalization could be divided into the following aspects:

\subsection{The legislation of civil servants occupation morality}

The legislation of civil servants occupation morality is easy to realize, due to direct experiences provided by the successful practice in western developed countries. However, it is quite complex and difficult to be executed in our country, because the civil servants occupation morality should be decomposed into more detailed and operational norms so that it is difficult to make them institutionalized. For instance, the regulation of civil servants property, the prohibition of using public power for private use, the prohibition of improper use of national property and undisclosed government information and etc. The above regulations always mixes public activities and private activities. CCCPC and State Bureau of Civil Servants carried out a series of theme-focused education about civil servants occupation morality in 2012. Compared with previous education, this education reached a good achievement that civil servants abandoned the thought, that is, morality was merely a soft constraint. Regarding civil servants occupation morality as a selection criteria and reward assessment, it is no longer a summon, but a legal power and a supreme authority. Thus it would become a bright guide for their career.

\subsection{Establishment and improvement of a punishment mechanism}

It includes the establishment of punishment and supervision agencies, the perfection of functions and permissions. The punishment can be divided into the judicial punishment, administrative punishment and legislative punishment. Under the leadership of legislative and administrative agencies, corresponding moral supervision and investigation committee are established to carry out the moral supervision and investigation. Meanwhile, the above specialized agencies are provided the authority for punishment and disclosure.

\subsection{The legislation of civil servants occupation morality in different departments}

According to the characteristics of specific departments, the civil servants occupation morality is refined and brought into daily works. Through the institutionalization of civil servants occupation morality, it includes both punishment against civil servants morality and rewards for exemplary performance of civil servants morality. In the actual process of the civil servants moral institutionalization, there has been a kind of bias named "Heavy Punishments, Light Rewards". On one hand, several departments have a one-sided understanding of negative punishments about civil moral institutionalization so that they ignore their positive guidance and incentive functions. On the other hand, punishments are easy to implement with respect to rewards. In addition, rewards are more difficult to operate compared with punishments, because rewards are not only material reward and spiritual recognition, but also the career implementation and promotion of civil servants, which is the most important interest of civil servants. To date, the democratization degree is not ideal enough, so that leaders' will and relationship with upper level play a quite important role when 
conducting occupational promotion. Therefore, moral factors are difficult to play their roles to the career future of civil servants. It is the most important reason for restricting the moral internalization of civil servants, which cannot be overcome in short terms. This is to say, our country should speed up the process of political democratization to make the civil servants occupation morality play its roles.

\section{The External Guarantee of the Legalization of Civil Servants Occupation Morality}

The legislation of civil servants occupation morality is a systematic project. The external guarantee of the legalization of civil servants morality is another important matter, which could be divided into three aspects.

\subsection{The democratic centralism system for the selection and appointment of civil servants}

The moral quality and popular sentiment should be regarded as considerations so as to minimize the leaders' intervention and cronyism. It can effectively reduce or prevent the violation of civil servants occupation moral opportunity. If most of the civil servants insist that promotion is lacking of fairness and justice, they would not only arise the psychological imbalance, but also regard the civil servants occupation morality as a "fig leaf". Meanwhile, those who are promoted by relationships could also make population feel insecure.

\subsection{Providing basic and dignified life for civil servants}

Because the living conditions of our citizens are far from the level of developed countries, people's ideological realm is also far beyond the priority of personal interests. Thus one of the main purposes of entering the civil service is to pursue a good living condition. However, several years later, they might feel that there is a big mismatch between their abilities and incomes, which could lead to the lacking of working enthusiasm and corruption. Therefore, it is important to make civil servants have a satisfied living condition, so that they have enough dignity and confidence to improve the civil servants morality.

\subsection{The refinement and implementation of civil servants morality in detailed works}

It not only overcomes the lack of abstract and generalization of civil servants moral requirements, but also makes civil servants morality become practical and operable. In recent years, some local governments have introduced a number of "never" regulations to implement the eight provisions of the central government. These regulations not only have a detailed, targeted and strong operability, but also avoid some vague utterances in the past regulations. The above regulations are successful examples of moral refinement and practice. They not only allow civil servants morality become visible, but also make it easy for a concrete consideration. It is gratified that similar regulations are being carried out by local governments throughout our country, and they could be able to produce a clean and honest civil service in future.

\section{Conclusion}

To sum up, there are two important dimensions of civil servants morality, the first dimension is to realize the normalization of civil servants morality education, another dimension is legalization of civil servants morality. Through revealing the law of morality, especially the standard of "the ability and moral integrity, the morality-first", it could further improve the civil servants to strengthen the voluntary of moral cultivation. Through the establishment and perfection of the civil servants morality legalization, it could further improve the civil servants to strengthen the consciousness of moral cultivation. Through combining the management innovation and educational innovation, it will effectively promote the civil servants to work with being honest and self-discipline. Therefore the civil servants occupation morality is the fundamental guarantee to ensure the smooth conduct of civil servants' job and to achieve their career. Through strengthening the civil servants occupation morality, civil servants would improve their occupation morality states, 
which are beneficial for both of themselves and population.

\section{References}

[1] Chen Wenxing. The Strengthening of Civil Servant Law and Civil Servant Supervision in China[J]. The Journal of Yunnan Administration College, 2005, 7(06): 92-95

[2] Xiao Nanbing. Talking about and Problems and Countermeasures of the Civil Servants' Supervision[J]. Science Mosaic, 2009, (12): 66-68.

[3] Li Dalin, Li Hao. Civilian Supervision Mechanism in Developed Countries and Regions and Its Revelation[J]. Jiangxi Social Science, 2008, (11): 135-139.

[4] Liu Lang, Xu Lifen, Wang Ming. Research on Surveillance Mechanism of Civil Servants Based on Mixed Strategy Combat[J]. Journal of Guangdong Institute of Public Administration, 2007, 19(03): 22-25.

[5] He Xiao. The Problems and Countermeasures of Current Civil Servants Occupation Morality Construction[D]. Renmin University of China, 2008.

[6] Wang Liying. On the Innovation of the Power Supervising and Restricting Mechanism[J]. Henan Social Science, 2003, 11(06): 118-120.

[7] Wei Shimei. Mechanism of the Masses Surveillance and Its Perfection in Fighting Against Corruption[J]. Journal of Henan University of Science \& Technology: Social Science, 2011, 29(03): 40-44.

[8] Wang Hongde, Jin Haishan. OfficialVirtue of Pre-Qin Confucian Thinking and its Redress of Civil Servant Professional Ethics[J]. Journal of Chuzhou University, 2015, (03): 54-58. 